\title{
EFFECT OF SALIVA CONTAMINATION AND RE-ETCHING TIME ON THE SHEAR BOND STRENGTH OF A PIT AND FISSURE SEALANT
}

\author{
EFEITO DA CONTAMINAÇÃO SALIVAR E DO TEMPO DE RECONDICIONAMENTO \\ ÁCIDO NA RESISTÊNCIA DA UNIÃO AO CISALHAMENTO DE UM SELANTE \\ DE FÓSSULAS E FISSURAS
}

Gisele Maria CORRER ${ }^{1}$, Angela S. CALDO-TEIXEIRA² ${ }^{2}$ Roberta Caroline Bruschi ALONSO ${ }^{1}$, Regina Maria PUPPIN-RONTANI ${ }^{3}$, Mário Alexandre Coelho SINHORETI ${ }^{4}$, Lourenço CORRER-SOBRINHO ${ }^{5}$

\footnotetext{
1- Doctoral in Dental Materials at Piracicaba Dental School - UNICAMP.

2- Doctoral in Pediatric Dentistry at Federal University of Santa Catarina - UFSC.

3- Titular Professor of Pediatric Dentistry at Piracicaba Dental School - UNICAMP.

4- Associate Professor of Dental Materials at Piracicaba Dental School - UNICAMP.

5- Titular Professor of Dental Materials at Piracicaba Dental School - UNICAMP.
}

Corresponding address: Regina Maria Puppin Rontani- Faculdade de Odontologia de Piracicaba - UNICAMP - Departamento de Odontologia Infantil - Área de Odontopediatria - Av. Limeira, 901 - Piracicaba - São Paulo - CEP 13414-903

Tel: (19)-3412-5286 / Fax: (19) 3412-5287 - e-mail: mpuppin@fop.unicamp.br

Received: October 10, 2003 - Returned for modification: November 11, 2003 - Accepted: January 27, 2004

\begin{abstract}
$T_{\mathrm{b}}$

The aim of this study was to evaluate the effect of saliva contamination (SCT) and re-etching time (RET) on the shear bond strength (SBS) of the Fluroshield sealant. Forty-five extracted third molars were sectioned and flattened until reach an enamel surface area. Then, all samples were etched for 30 sec with 35\% phosphoric acid and then they were distributed into 9 groups ( $\mathrm{n}=10$ ) according to SCT and RET (seconds), respectively: G1- control (no SCT and no RET); G2- 30s and 0s; G3- 60s and 0s; G4-30s and 2s; G5- 30s and 5s; G6- 30s and 15s; G7-60s and 2s; G8- 60s and 5s; G9- 60s and 15s. The sealant was applied according to the manufacturer's instructions. The samples were stored in distilled water at $37^{\circ} \mathrm{C}$ for $72 \mathrm{~h}$ and subjected to the SBS test. The results indicated that there was no statistically significant difference between the groups (p>0.05). However, it could be noticed that: 1- the longer the SCT, the lower the SBS values; 2 - the longer the RET, the higher the SBS values. It could be concluded that there was a tendency to the shortest SCT (30s) associated to the longest RET (5 and 15s) to reach similar SBS values for the control group.

Uniterms: Saliva contamination; Sealant; Re-etching time; Shear bond strength.
\end{abstract}

\section{RESUMO}

propósito deste estudo foi avaliar o efeito do tempo de contaminação salivar (TCS) e de recondicionamento ácido (TRA) na resistência da união ao cisalhamento (RC) do selante Fluroshield. Foram selecionados 45 terceiros molares. Os dentes foram seccionados no sentido mésio-distal e suas superfícies foram lixadas até a obtenção de uma área plana em esmalte. Em seguida, as amostras foram distribuídas aleatoriamente em 9 grupos $(n=10)$, em função do TCS e TRA (segundos), respectivamente: G1 - controle; G2 - 30 e 0; G3 - 60 e 0; G4 - 30 e 2; G5 - 30 e 5; G6 - 30 e 15; G7 - 60 e 2; G8 - 60 e 5; G9 - 60 e 15 . Em seguida, foi realizada a aplicação do selante de acordo com as instruções do fabricante. Os corpos-de-prova obtidos foram armazenados em água destilada a $37^{\circ} \mathrm{C}$ por 72 horas, e então submetidos ao ensaio de cisalhamento à velocidade de $0,5 \mathrm{~mm} / \mathrm{min}$. Os resultados foram submetidos à análise de variância (ANOVA), e indicaram que não houve diferença estatística significativa (p>0,05) entre todos os grupos. Observou-se que: 1 - quanto maior o TCS, menores os valores de RC (MPa); 2- quanto maior o TRA, maior o valor de RC (MPa). Pôde-se concluir que houve uma tendência para o menor TCS (30s) e os maiores TRA (5 e 15s) em retornar aos valores de RC do grupo controle.

Unitermos: Contaminação salivar; Selante; Recondicionamento ácido; Cisalhamento. 


\section{INTRODUCTION}

Prevention is the main objective of modern dentistry, mainly in pediatric dentistry, since $88 \%$ of the carious lesions in children are located in pits and fissures ${ }^{10}$. This high incidence of occlusal caries in children is due to the easy accumulation of bacteria and nutrients in the pits and fissures close of the dentin-enamel junction, and to the difficulty or inability of mechanical cleaning of this area ${ }^{19}$.

An alternative to revert this situation is the application of a physical barrier through pit and fissure sealing. This preventive technique has been widely used since its appearance with Cueto and Buonocore ${ }^{5}$ (1967). It is also known that fluoride plays an important role in the prevention of carious lesions, acting in the de-remineralization process and also because of its antibacterial potential. However, there is little information about the antibacterial potential of fluoridated pit and fissure sealants. Kozai, et al. ${ }^{16}$ (2000) suggested that the differences in the antibacterial activity presented by the tested materials were due to the concentrations of fluoride ion release or $\mathrm{pH}$ alterations. Therefore, in order to obtain long-term success with sealants, the first and perhaps the most important condition is the maintenance of a satisfactory retention of the material to enamel $^{7-9}$. It is known that the resin-enamel bond is satisfactory. Nevertheless, any contamination of the substrate harms the sealant retention capacity.

The main cause of sealant failure is the saliva contamination after enamel acid etching $7,8,13,15,20$. Thomson, et al. ${ }^{20}$ (1981) reported that sealants applied to enamel contaminated by saliva and not washed presented lower shear bond strength values than the enamel not contaminated or contaminated and washed. The brief contact, about 1 second, of the etched enamel with saliva results in the formation of an adherent layer that covers the pores created by the acid etching and harms the bond of the sealant to the substrate ${ }^{18}$.

Saliva contamination is critical, mainly when the intention is the accomplishment of sealing of permanent molars in the early stage of eruption ${ }^{8}$, which are more susceptible to caries due to the difficulty to clean this area. Several studies have been carried out in order to improve the retention of sealants to enamel, even in conditions of saliva contamination. A modification of the sealant application technique was proposed by Hitt and Feigal ${ }^{14}$ (1992), with the use of a dentin bonding agent layer between the etched enamel and the sealant, known as intermediate layer. Some studies confirmed the benefits of the application of bonding agents under sealants in etched enamel that was contaminated by saliva. Such studies showed reduction of microleakage $\mathrm{e}^{2,13}$ and increase in the retention rate of the sealant ${ }^{7,9}$. Other studies demonstrate that it is possible to use a dentin bonding agent, OptiBond, as pit and fissure sealant with good clinical results and acceptable performance under conditions of contamination $^{10-11}$.

However, sometimes it is very difficult to visualize if saliva contamination took place, and what should be done to avoid sealant failure when it occurs.
Some authors recommend re-etching of the contaminated enamel ${ }^{18,19,22,23}$. However, the optimal time for this procedure is not defined. This way, different contamination times as well as different re-etching times may alter the bond strength and retention of the sealant.

The purpose of this study was to test the null hypothesis that neither contamination nor re-etching times will affect the bond strength of Fluroshield ${ }^{\circledR}$ sealant to enamel.

\section{MATERIALAND METHODS}

\section{Shear bond strength test}

Forty-five recently extracted third-molars were selected, cleaned and stored in $0.5 \%$ Chloramine $\mathrm{T}$ solution for up to 2 months after extraction. The roots were sectioned $1 \mathrm{~mm}$ below the cementoenamel junction, and the crowns were transversally sectioned in mesio-distal direction with a double-faced diamond saw (KG Sorensen, São Paulo, SP, Brazil). The crown segments were mounted in a $3 / 4$-inchdiameter PVC ring parallel to the base, and the rings were then filled with self-curing polystyrene resin. The embedded specimens were ground on a water-cooled mechanical polisher (Minimet 1000, Buheler, UK LTD, Lake Bluff, IL 60044 - USA) using 320-, 400- and 600-grit silicon carbide abrasive paper (Carbimet Disc Set, \#305178180, Buheler, UK LTD, Lake Bluff, IL 60044 - USA) to expose a flat enamel area of $3 \mathrm{~mm}$ in diameter on the lingual or buccal surfaces.

The specimens were randomly assigned to nine groups $(n=10)$. Before surface treatment, the enamel surface was covered using an adhesive tape with a 3-mm-diameter hole. The samples were cleaned with pumice and the flat surface was etched with 37\% phosphoric acid (Etching Dental Gel Dentsply/Caulk, Milford, DE, USA, 19963-batch n ${ }^{\circ .}$ 63440) for 30 seconds, washed for 20 seconds and dried for 20 seconds. Then, a nylon matrix (diameter: $2.93 \mathrm{~mm}$ and height: $3.0 \mathrm{~mm}$ ) was placed on the flat enamel surface and fixed with wax.

The sealant used in this study was Fluroshield ${ }^{\circledR}$ (Dentsply/Caulk, Milford, DE, USA, 19963 - batch n ${ }^{\circ}$ 63029), which was applied using a Centrix syringe in the nylon matrix. Two increments were individually light-cured for 20 seconds with a light-curing unit (Elipar Tri-Light, ESPE Co. Germany, D-82229, Seefeld, Germany). Light intensity was periodically measured in the unit and ranged from 580 to $720 \mathrm{~mW} / \mathrm{cm}^{2}$.

The groups subjected to saliva contamination were contaminated by the operator's integral and recently collected saliva, prior to application of the material.

The procedures for saliva contamination and re-etching are described in Table 1.

For Group 1, the sealant was applied according to the manufacturer's instructions, without saliva contamination or re-etching. The contamination procedure was carried out after enamel etching. Contaminated groups were always washed for $15 \mathrm{~s}$, followed by drying for 15 s before being reetched or not.

After bonding procedure, the samples were stored in 
distilled water for $72 \mathrm{~h}$, at $37^{\circ} \mathrm{C} \pm 1^{\circ} \mathrm{C}$. Next, they were subjected to the shear bond strength test in a Universal Testing Machine (Instron Corp, Canton, MA 02021, model 4411 ) at a crosshead speed of $0.5 \mathrm{~mm} / \mathrm{min}$. The data were analyzed by one-way ANOVA test at the $95 \%$ confidence level.

\section{Fracture mode evaluation}

All failure sites produced by the shear bond strength test were observed with a Stereomicroscope (Model XLT30 - Nova Optical Systems - Novo Tempo Co. e Participações LTDA, Piracicaba - São Paulo- Brasil, 13414-000) at 25X magnification in order to classify the fracture mode as cohesive (in enamel or in the sealant), adhesive (between the sealant and the enamel) or mixed (cohesive and adhesive). Three representative samples of each group were selected for analysis in a scanning electron microscope (SEM

TABLE 1- Distribution of the groups according to saliva contamination and re-etching times

\begin{tabular}{lcl}
\hline Group & $\begin{array}{r}\text { Contamination } \\
\text { time (s) }\end{array}$ & $\begin{array}{c}\text { Re-etching } \\
\text { time (s) }\end{array}$ \\
\hline 1 & No & No \\
2 & 30 & No \\
3 & 60 & No \\
4 & 30 & 2 \\
5 & 30 & 5 \\
6 & 30 & 15 \\
7 & 60 & 2 \\
8 & 60 & 5 \\
9 & 60 & 15 \\
\hline
\end{tabular}

$$
\text { - JEOL - JSM 5600/5600 LV, Tokyo, 196-0021, Japan). }
$$

\section{RESULTS}

The shear bond strength (SBS) means for the nine groups are shown in Table 2 .

There were no significant differences between all tested groups ( $p>0.05$ ); therefore, the tested hypothesis must be accepted. Contamination for either 30 or 60 seconds did not affect the bond strength of the sealant to enamel, regardless of the re-etching procedure. When enamel was contaminated for 30s, there was a tendency of the bond strength to return to control values when re-etching was performed for 5 or 15 seconds. Such tendency was not observed when enamel was contaminated for $60 \mathrm{~s}$.

The fracture patterns are shown in Table 3 and Figures 1 and 2. The most frequent failure modes were mixed (52.2\%) and adhesive (40.2\%). Only three specimens presented cohesive failure in enamel (3.5\%) and one specimen

TABLE 2- Shear Bond Strength (MPa) according to saliva contamination and re-etching time

\begin{tabular}{cll}
\hline Groups & Mean* $^{*}$ & S.D ( \pm$)$ \\
\hline 1 & 7.72 & 0.41 \\
2 & 4.99 & 0.76 \\
3 & 4.78 & 0.67 \\
4 & 3.82 & 0.65 \\
5 & 6.70 & 0.52 \\
6 & 8.14 & 0.70 \\
7 & 5.43 & 0.58 \\
8 & 6.08 & 0.33 \\
9 & 5.41 & 0.73 \\
\hline
\end{tabular}

* There was no statistically significant difference among values $(p>0.05)$

TABLE 3- Distribution of failure modes (\%) as determined under light microscope, $25 \mathrm{X}$ magnification

\begin{tabular}{lllll}
\hline Groups & adhesive & mixed & $\begin{array}{l}\text { Failure mode (\%) } \\
\text { cohesive (enamel) }\end{array}$ & cohesive (material) \\
\hline 1 & 50 & 30 & 20 & - \\
2 & 77.7 & 22.3 & - & - \\
3 & 30 & 70 & - & - \\
4 & 70 & 30 & - & - \\
5 & 30 & 70 & - & - \\
6 & 30 & 70 & - & - \\
7 & 12.5 & 87.5 & - & 10 \\
8 & 20 & 70 & 10 & - \\
9 & 40 & 50 & & - \\
\hline
\end{tabular}


presented cohesive failure in the sealant (1.1\%).

\section{DISCUSSION}

The main factor contributing to the optimum performance of a pit and fissure sealant is the retention capacity of the material to the dental structure. It is known that conditioning of the enamel surface with phosphoric acid increases the enamel surface energy, making the substrate more receptive to bonding with sealant. However, the bonding ability between the sealant and the acid-etched enamel is dependent on small variations in the etching, washing and drying time ${ }^{24}$.

Saliva contamination during sealing is the main cause of failure of sealants.

Two factors should be taken into account regarding the saliva contamination: 1 - surface changes - saliva contamination allows the formation of an organic adherent film that recovers the surface of the conditioned enamel and cannot be removed by the conventional washing technique; 2 - moisture of the substrate - after contamination, if the substrate is not properly dried before sealant application, sealing will probably fail due to the hydrophobic nature of sealants.

In this study, there was no difference in the SBS values between contaminated and non-contaminated specimens, regardless of the time of contamination. It probably occurred because, after saliva contamination, the specimens were vigorously washed and then properly dried before sealant application. Thus, although saliva contamination on the conditioned enamel facilitates the formation of a film that covers the substrate surface, it was not sufficient to damage the sealant retention, as seen in Figures 1 and 2, which display mixed failures found in Groups 1 (control) and 6 (contaminated).

This is in agreement with the results found by Thomson, et al. ${ }^{20}$ (1981), who did not find difference in the SBS values between the contaminated and washed specimens and those not contaminated. However, for the contaminated and not washed specimens there was a significant reduction in the SBS values. Other researchers also did not find significant

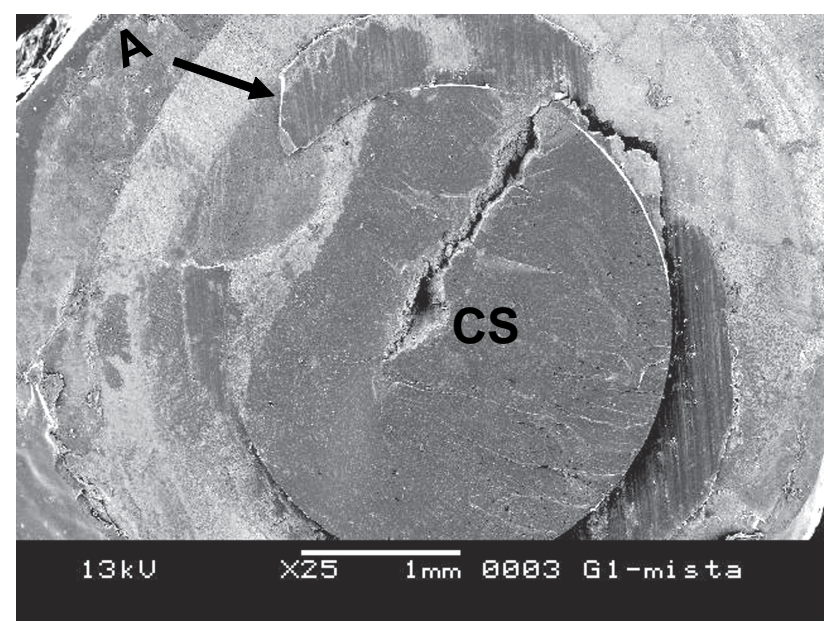

FIGURE 1- SEM photomicrograph illustrating a mixed failure for Group 1 (A - adhesive; CS - cohesive in sealant) differences between contaminated and non-contaminated groups, using several adhesive systems ${ }^{1,6,12,15}$.

This way, to overcome the contamination problem some authors recommends washing and re-etching of the contaminated enamel ${ }^{18,19,22,23}$. However, the optimal time for this procedure is not defined.

In this study, three different re-etching times, 2, 5 and 15 seconds, and 2 different times of saliva contamination, 30 and 60 seconds were tested. The results demonstrated a decrease in the SBS values for the specimens contaminated by saliva for 30 and 60 seconds, as well as an increase in the SBS values with the increase in time of acid re-etching in the specimens contaminated for 30 seconds. This increase was not observed for groups contaminated for 60 seconds. However, overall comparisons indicate no significant effects of contamination and re-etching times. Similar findings were previously reported by Puppin-Rontani, Garcia-Godoy and Jackson ${ }^{17}$ (1999).

Although there was no significant influence of the reetching time on the shear bond strength, there was a tendency of higher bond strength values of the sealant to contaminated enamel with the increase in re-etching time. This indicate that, upon contamination in a clinical situation, clinicians are advised to extend the re-etching time for 15 seconds or more to reduce the potential risk of sealant failure.

Many researchers have proposed other forms to reduce sealant failures by placing a layer of a dentin bonding agent (intermediate layer) between the sealant and the acid-etched and contaminated enamel. Several studies demonstrate that this intermediate layer is capable of reducing microleakage in the specimens contaminated by saliva ${ }^{2,13,21}$ and to improve the retention rate of the sealant in conditions of contamination $^{7-9,14}$. This is due to the fact that the bonding systems used between the hydrophobic sealant and the substrate are hydrophilic. Therefore, they are capable to function in moist conditions (contamination), facilitating the penetration of the adhesive inside the enamel porosities through the organic film that covers the substrate after contamination. These adhesive systems can be used as pit and fissure sealants themselves, presenting good

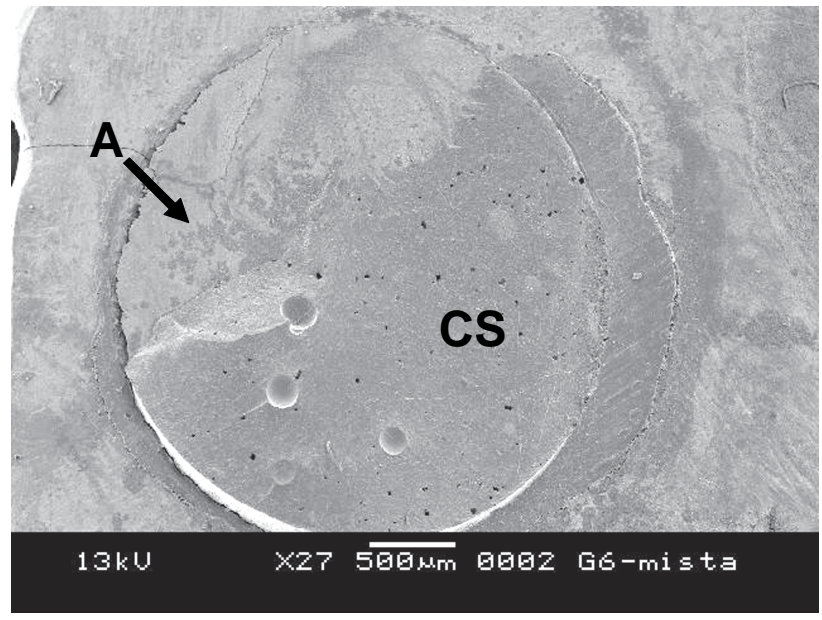

FIGURE 2- SEM photomicrograph illustrating a mixed failure for Group 6 (A - adhesive; CS - cohesive in sealant) 
performance as to the microleakage and clinical use ${ }^{10,11}$.

Conversely, Boksman, et al. ${ }^{3}$ (1993) found no clinical improvement in the use of bonding agents in association with pit and fissure sealants. In that way, the cost/benefit of such approach would prevent its use in governmental preventive programs, where low cost and improved benefits are desirable.

It should be pointed out that, although the results of this study demonstrate no significant effect of saliva contamination on the bond strength of the sealant to enamel, it is recommended that clinicians take proper care during sealant application to avoid the risk of contamination.

Clinical and laboratory studies should be conducted, to observe if those factors would compromise the microleakage due to the presence of an amorphous layer on the enamel surface produced by saliva contamination.

\section{CONCLUSION}

1 - There was no statistically significant difference between all the roups ( $\mathrm{p}>0.05)$.

2 - Regarding numerical means, the longer the SCT, the lower the SBS values (MPa) for Groups 2 and 3; the longer the RET, the higher the SBS values (MPa) for Groups 4, 5 and 6, considering SCT 30s. Considering the contamination for 60s (groups 7, 8 and 9), this condition was not found.

3 - There was a tendency for shorter SCT (30s) and longer RET (5 and 15s) in reestablishing the initial SBS values, as in the control group.

\section{REFERENCES}

1- Abdalla AI, Davidson CL. Bonding efficiency and interfacial morphology of one-bottle adhesives to contaminated dentin surfaces. Am J Dent 1998 Dec; 11(6):281-5.

2- Borem LM, Feigal RJ. Reducing microleakage of sealants under salivary contamination: digital-image analysis evaluation. Quintessence Int 1994 Apr; 25(4):283-9.

3- Boksman L, McConnel RJ, Carson B, McCutcheon-Jones EF. A 2year clinical evaluation of two pit and fissure sealants placed with and without the use of bonding agent. Quintessence Int 1993 Feb; 24(2):131-3.

4- Buonocore MGA. Simple method of increasing the adhesion of acrylic filling materials to enamel surfaces. J Dent Res 1955 Dec; 34(6):849-53.

5- Cueto EI, Buonocore MGA. Sealing of pits and fissures with an adhesive resin: its use in caries prevention. J Am Dent Assoc 1967 Jul; 75:121-8.

6- eL- Kalla IE, Garcia-Godoy F. Saliva contamination and bond strength of a single-bottle adhesives to enamel and dentin. Am J Dent 1997 Apr; 10(2):83-7.

7- Feigal RJ, Musherure P, Gillespie B, Levy-Polack M, Quelhas I, Hebling $\mathrm{J}$, et al. Improved sealant retention with bonding agents: a clinical study of two-bottle and single-bottle systems. J Dent Res 2000 Nov; 79(11):1850-6.
8- Feigal RJ. Sealant and preventive restorations: review of effectiveness and clinical changes for improvements. Pediatr Dent 1998 Sep/Oct; 20(2):85-92.

9- Feigal RJ, Hitt JC, Splieth C. Retaining sealant on salivary contaminated enamel. J Am Dent Assoc 1993 Mar; 124(3):88-97.

10- Grande RH, Pedroso de Lima AC, Rodrigues-Filho LE, Witzel MF. Clinical evaluation of an adhesive used as a fissure sealant. Am J Dent 2000 Aug; 13(4):167-70.

11- Grande RH, Ballester RY, Singer MJ, Santos JFF. Microleakage of a universal adhesive used as a fissure sealant. Am J Dent 1998 Jun; 11(3):109-13.

12- Hansen EK, Munksgaared EC. Saliva contamination versus efficacy of dentin-bonding agents. Dent Mater 1989 Sep; 5(5):329-33.

13- Hebling J, Feigal RJ. Use of one-bottle adhesive as an intermediate bonding layer to reduce sealant microleakage on saliva contaminated enamel. Am J Dent 2000 Aug; 13(4):187-91.

14- Hitt JC, Feigal RJ. Use of a bonding agent to reduce sealant sensitivity to moisture contamination: an in vitro study. Pediatr Dent 1992 Jan/Feb; 14(1):41-6.

15- Johnson ME, Burguess JO, Hermesch CB, Buikema A DJ. Saliva contamination of dentin bonding agents. Oper Dent 1994 Nov/Dec; 19(6):205-10.

16- Kozai K, Suzuki J, Okada M, Nagasaka N. In vitro study of antibacterial and antiadhesive activities of fluoride-containing lightcured fissure sealants and a glass ionomer liner/base against oral bacteria. ASDC J Dent Child 2000 Mar/Apr; 67(2):117-22.

17- Puppin-Rontani RM, Garcia-Godoy F, Jackson D. Effect of saliva contamination on the shear bond strength of a sealant. J Dent Res 1999 May; 78(5):965.

18- Silverstone LM, Hicks MJ, Feathertone MJ. Oral fluid contamination of etched enamel surfaces: an SEM study. J Am Dent Assoc 1985 Mar; 110(3):329-32.

19- Tandon S, Kumari R, Udupa S. The effect of etch-time on the bond strength of a sealant and on the etch-pattern in primary and permanent enamel: an evaluation. ASDC J Dent Child 1989 May/ Jun; 56(3):186-90.

20- Thomson JL, Main C, Gillespie FC, Stephen KW. The effect of salivary contamination on fissure sealant - enamel bond strength. J Oral Rehabil 1981 Jan; 8(1):11-8.

21- Tulunoglu Ö, Bodur H, Uçtasli M, Alaçam A. The effect of bonding agents on the microleakage and bond strength of sealant in primary teeth. J Oral Rehabil 1999 May; 26(5):436-41.

22- Vertuan V, BarelliI N, Da Costa Serra M. Pit and fissure sealants. Results of different times of salivary contamination of the acid conditioned enamel surface. Scanning electron microscopic study. RGO 1988 Nov/Dec; 36(6):421-5.

23- Xie J, Powers JM, McGuckin RS. In vitro bond strength of two adhesives to enamel and dentin under normal and contaminated conditions. Dent Mater 1993 Sep; 9(5):295-9.

24- Williams B, Von Fraunhofer JA. The influence of the time of etching and washing on the bond strength of fissure sealants applied to enamel. J Oral Rehabil 1977 Apr; 4(2):139-43. 